\title{
Globalization and Firms' Financing Choices: Evidence from Emerging Economies
}

\author{
By: Sergio Schmukler and Esteban Vesperoni
}

William Davidson Working Paper Number 388

May 2001 


\title{
Globalization and Firms' Financing Choices: Evidence from Emerging Economies
}

\author{
Sergio Schmukler \\ World Bank \\ and \\ Esteban Vesperoni \\ International Monetary Fund
}

May 15, 2001

JEL Classification Codes: F3, G1, G3

Keywords: financing choices, financial structure, financial integration, financial globalization, international financial markets

\footnotetext{
* We are grateful to Stijn Claessens, Asli Demirgüç-Kunt, Vihang Errunza, Ricardo Ffrench Davis, Leonardo Hernandez, Chang Hsieh, Patrick Honohan, Daniel Lederman, Ross Levine, Rick Mishkin, Raghu Rajan, Luis Serven, and Jeff Williamson for their useful comments and suggestions. We have also benefited from feedback received at the World Bank conference on "Financial Structure and Economic Development," the LACEA Meetings in Rio de Janeiro, Brazil, the Winter Camp in International Finance in Santiago, Chile, and the Joint IMF/World Bank Research Seminar. We thank Simon Altkorn Monti, Thorsten Beck, Simeon Djankov, Dori Flanagan, Jack Glen, Himmat Kalsi, Ashoka Mody, and David Sekiguchi for help with the data. We are grateful to Rina Bonfield, Federico Guerrero, Cicilia Harun, Emir Keye, Jon Tong, and Chris van Klaveren for excellent research assistance. The findings, interpretations, and conclusions expressed in this paper are entirely those of the authors and do not necessarily represent the views of the International Monetary Fund or the World Bank. Contact address: World Bank, $1818 \mathrm{H}$ Street NW, Washington, DC 20433. Phone (202) 458-4167. Fax: (202) 522-3518. E-mail addresses: sschmukler@worldbank.org and evesperoni@imf.org
} 


\title{
Globalization and Firms' Financing Choices: Evidence from Emerging Economies
}

\begin{abstract}
This paper studies the relation between firm's financing choices and financial globalization. Using an East Asian and Latin American firm-level panel for the 1980s and 1990s, we study how leverage ratios, debt maturity structure, and sources of financing change when economies are liberalized and when firms access international capital markets. We find that debt-equity ratios do not increase after financial liberalization. Debt maturity shortens for the average firm when countries undertake financial liberalization. However, domestic firms that actually participate in international capital markets extend their debt maturity. Financial liberalization has less effects on firms from countries with more developed domestic financial systems. Leverage ratios increase during crises.
\end{abstract}




\section{Globalization and Firms' Financing Choices: Evidence from Emerging Economies}

The 1990s witnessed increasing financial integration of emerging countries with world capital markets. Emerging markets lifted restrictions on cross-country capital movements, subsequently receiving large capital inflows. Foreign direct investment (FDI) and portfolio flows became the main components of capital flows to emerging markets, primarily through purchases of bonds and equity. As a consequence, companies from emerging economies became active participants in international financial markets. As emerging markets relied more on foreign financing, crises erupted in Mexico (1994), Thailand (1997), and Russia (1998), with strong spillover effects across countries.

The events of the last decade and the prospects for increasing integration have generated discussions on the pros and cons of "financial globalization." free capital mobility allows consumption smoothing and risk sharing across countries, creating new investment and financing opportunities. Also, more integration leads to the development of the financial system, increasing transparency and market discipline and improving the market infrastructure. On the other hand, faced with new financing opportunities, domestic borrowers might take new risk. Also, open economies can become dependent on foreign capital and vulnerable to capital flow reversals or potential disturbances in international markets, what can trigger financial crises.

The existing literature already studies several aspects of financial globalization. The finance literature tends to concentrate on the potential benefits of globalization. For

\footnotetext{
${ }^{1}$ By financial globalization we mean the integration of domestic financial systems with international financial markets.
} 
example, it analyzes the effects of stock market liberalization on asset prices and investment, using aggregate data. Standard international asset pricing models predict that stock market liberalization reduces the cost of equity capital because, among other things, it allows risk sharing between domestic and foreign investors. Bekaert and Harvey (2000), Henry (2000a and 2000b), and Kim and Singal (2000), among others, find evidence consistent with the prediction that stock market liberalization increases equity prices and investment. The evidence also suggests that there is no increase in volatility of stock returns.

Another strand of the finance literature examines firm-level data to study a different aspect of globalization, the cross listing of domestic stocks on major world stock exchanges. These papers concentrate on abnormal returns, volatility, cost of capital, and liquidity. See, for example, Alexander, Eun, and Janakiramanan (1988), Chan, Fong, and Stulz (1995), Foerster and Karolyi (1996), Domowitz, Glen, and Madhavan (1998), Hargis and Ramanlal (1998), Errunza and Miller (1999), and Miller (1999). Overall, the papers find evidence of abnormal positive returns and lower cost of capital after cross listing. Moreover, cross listing is associated with higher liquidity and lower volatility.

The international finance literature also analyzes the effects of globalization. Though the literature discusses the benefits and costs of globalization (like Obstfeld 1998), a large body of work concentrates on one of the potential costs of globalization, namely on financial crises. Part of this literature focuses on the link between financial liberalization and crises; the argument is that globalization leads to more risk taking and

\footnotetext{
${ }^{2}$ See, for example, Stapleton and Subrahmanyan (1977), Alexander, Eun, and Janakiramanan (1987), Errunza (1999), and Stultz (1999).
} 
higher vulnerabilities. For example, McKinnon and Pill (1997) argue that financial liberalization can lead to overborrowing syndromes, increasing the likelihood of crises. Implicit government guarantees might prompt banks to engage in moral hazard lending and drive economies to over-investment cycles. Kaminsky and Reinhart (1999) find that financial liberalization might lead to lending booms, which precede banking and currency crises.

Although the existing literature already provides evidence on some of the effects of globalization, important aspects of this process are still unexplored. The goal of this paper is to shed light on a different dimension of globalization. We examine firm-level data to study the relation between the globalization of financial markets and firms' financing choices (also known as financial structure). We focus on balance sheet data to analyze: (i) the choice between equity and debt financing, (ii) the maturity structure of debt financing, and (iii) the choice between internal and external financing. To do so, we concentrate on the behavior of four key ratios: debt over equity, long-term debt over equity, short-term debt over total debt, and retained earnings over total liabilities. As explained in the next section, firms' financial choices have already been analyzed in the literature, but not in the context of globalization.

Our focus on balance sheet data is useful to understand new aspects of the globalization process. First, we are able to study the relation between macroeconomic factors (like financial liberalization, domestic financial development, and crises) and firms' financing choices. This relation is important because, among other things, the liberalization of the domestic financial sector might create new financing opportunities 
for a closed economy. On the other hand, firms might take new risk when financial systems are deregulated, possibly leading to the deterioration of balance sheets. As Krugman (1999) argues, deteriorated balance sheets can play a crucial role during crises and in their aftermath. Our data on balance sheets can provide direct evidence on how firms' financial structure is affected by different macroeconomic factors.

Second, balance sheet data enable us to study inter-firm differences within the same macro framework. Our micro data allow us to examine how firms' access to international debt and equity markets is associated with financial structure. This is important because not all firms tend to have access to international capital markets, even when the financial sector is liberalized. If markets are segmented (if globalization opens new financing opportunities only to some firms), there will be differences in the financial structure of firms with and without access to international markets.

To study the effects of globalization on financing choices, this paper uses a novel data set. We construct a large panel of non-financial companies located in East Asia and Latin America. We work with seven emerging market countries that experienced sharp financial liberalization processes and crises. Since we have long time series, we are able to include periods characterized by crises, stability, financial restrictions, and financial liberalization. Our data comprise firms from Argentina, Brazil, Indonesia, Malaysia, Mexico, South Korea, and Thailand. The data cover the 1980s and 1990s. We gather information on balance sheets, firms' characteristics, participation of companies in international bond and equity markets, and country affiliation of firms. 
We measure globalization with macro and micro variables. The macro variable captures when a country opens up its financial system to the rest of the world. To construct the macro variable we use dates of stock market liberalization, which have been widely used in the existing literature. Alternative measures, which use more comprehensive indicators of liberalization, show that the years of stock market liberalization coincide with the years of a more general liberalization of both the domestic financial sector and the capital account of the balance of payments. To construct the micro variables we use the dates in which firms issue bonds and equity in foreign capital markets.

The rest of the paper is organized as follows. Sections I and II discuss the methodology and data. Section III presents the basic results. Section IV shows the results using alternative specifications. Section V concludes.

\section{Methodology}

There now exists a series of empirical papers that study the financing choices of firms. This literature concentrates on the choice between debt and equity and on the maturity structure of debt. The focus of the literature is to test hypotheses developed in the theoretical literature on corporate finance, like the pecking order hypothesis (Myers 1984 and Myers and Majluf 1984). The domestic finance literature (e.g., Titman and Wessels 1993 and Opler and Titman 1996) studies the evidence available for the U.S. Rajan and Zingales (1995) analyze the case of industrial countries. Booth, Aivazian, 
Demirgüç-Kunt, and Maksimovic (2001) study the case of 10 developing countries during the 1980s.

To study financing choices in the context of financial globalization, we follow the methodology applied by the current literature. But we use a new database that covers a longer time span and contains more variables than existing databases. We include data for the 1990s and variables that measure the integration of countries and firms with international financial markets.

The four dependent variables we study are the following. The debt-equity variable tracks the evolution of total debt and is defined as the ratio between total liabilities and the book value of equity. Long-term debt over equity is the ratio between long-term liabilities and the book value of equity. The third variable, short-term debt over total debt, captures the behavior of firms' debt maturity structure. The fourth variable, retained earnings over total debt, describes the importance of internal financing.

The explanatory variables can be grouped into four different categories: (i) firms' characteristics, (ii) macroeconomic factors, (iii) access to international capital markets, and (iv) country effects.

The variables in the first category focus on key characteristics of firms. ${ }^{\mathrm{D}}$ The first variable in this category is the logarithm of firms' net fixed assets, which is a proxy for the size of firms. The second variable, the ratio of firms' net fixed assets over total assets,

\footnotetext{
${ }^{3}$ There also exist some case studies analyzing Ecuador, India, and Chile; see Jaramillo and Schiantarelli (1996), Schiantarelli and Srivastava (1996), and Gallego and Loayza (2000).

${ }^{4}$ The ideal variable to measure retained earnings would be retained earnings/total investment. However, the lack of firms' detailed flow statements does not allow us to use this variable.

${ }^{5}$ These variables have been identified by the literature on corporate finance as important determinants of agency costs that influence firms' financing choices (see, for example, Booth, Aivazian, Demirgüç-Kunt, and Maksimovic 2001).
} 
is an indicator of asset tangibility. The third variable, firms' profits after taxes over total assets, captures the capacity of firms to generate internal resources. Finally, we also include a new variable, which reflects the production mix. This is a time-invariant dummy variable that takes the value one if the firm is a producer of tradable goods, and zero otherwise. Tradable producers have the capacity to generate revenues in foreign currency; thus, they might be able to obtain different financing opportunities, as discussed in Caballero and Krishnamurthy (1998).

The second category involves macroeconomic variables that affect firms' financing. The first variable, financial liberalization, captures the effect of stock market liberalization on financial structures. The second variable is related to financial crises. We use dummy variables for the years 1995, 1997, 1998, corresponding to the Mexican crisis

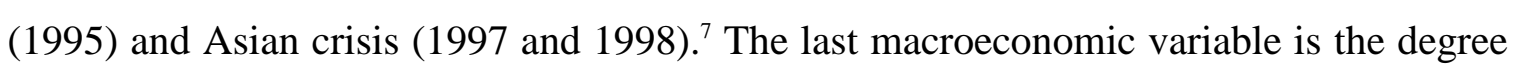
of domestic financial development interacted with the financial liberalization dummy. This interaction captures whether financial liberalization affects financially underdeveloped economies more than financially developed countries.

The variables in the third category measure the effects of expanding the financing opportunities through access to international bond and equity markets. The variable capturing access to international bond markets is a dummy variable that takes the value one for the periods in which a given firm issues bonds in international capital markets, and zero otherwise. Thus, this variable captures not only the ability to access international markets but also the actual participation of firms in those markets. The variable capturing

\footnotetext{
${ }^{6}$ The capacity to generate revenues in foreign currency is viewed as one of the most important factors to obtain international collateral and, therefore, gain access to external financing.
} 
access to international equity markets is defined as a dummy variable that takes the value one from the moment that a firm starts trading or starts raising capital in international equity markets, and zero otherwise.

As a last category, we include country dummies to control for the nationality of firms. This is important in light of previous work on corporate finance. Demirgüç-Kunt and Maksimovic (1996) find that country characteristics, such as the efficiency of legal institutions and the development of capital markets in different countries, are important in explaining differences in firms' capital structure.

We estimate panel regressions for every dependent variable. The basic regression uses data for the seven emerging economies in the sample; it is a pooled panel that allows for heteroskedasticity of the residuals. Additionally, we estimate three alternative specifications to check for the robustness of the results. ${ }^{1}$ The first alternative specification estimates separate panels for the East Asian and Latin American economies to determine if there are regional differences. The equations estimated for the pooled panels are:

$$
Y_{i, c, t}=\eta^{\prime} n_{c}+\pi^{\prime} p_{i, c}+\beta^{\prime} X_{i, c, t}+\gamma^{\prime} A_{i, c, t}+\theta^{\prime} M_{c, t}+\omega_{i, c, t},
$$

such that $i=1, \ldots, N, c=1, \ldots, C$, and $t=1, \ldots, T$.

\footnotetext{
${ }^{7}$ The year 1998 also captures the Russian crisis, which many regard as part of the Asian crisis.

${ }^{8}$ We define this variable differently than the variable capturing access to international bond markets because some firms trade their equity in international markets without raising new capital. This can take place through issuance of depositary receipts in international markets using equity outstanding in domestic markets. As an alternative approach to measure access to international equity markets, we also used the ratio of value traded in depositary receipts to the value traded in domestic markets. The results do not change significantly when using this alternative variable.

${ }^{9}$ In fact, we also estimate a logistic transformation of the variable short-term debt over total debt as another alternative, because the variable is bounded between 0 and 1 . The results are very similar. Therefore, we report the results without the transformation to make our results comparable with the existing literature.
} 
$Y_{i, c, t}$ represents the four dependent variables defined above, which measure firms' financing choices. The sub-indexes $i, c$, and $t$ stand for firm, country, and time respectively. $X_{i, c, t}$ stands for the three variables capturing firms' characteristics. $A_{i, c, t}$ denotes access to international financial markets. $M_{c, t}$ captures the macroeconomic variables, which only vary with time and countries but not across firms. $n_{c}$ stands for the country fixed effect. $p_{i, c}$ stands for the production mix.

As a second alternatively, we report within (or fixed effects) estimates. These estimates do not include country specific effects and the production mix variable because they are perfectly collinear with firm dummies. The within models estimated are:

$$
Y_{i, c, t}=\phi^{\prime} f_{i, c}+\beta^{\prime} X_{i, c, t}+\gamma^{\prime} A_{i, c, t}+\theta^{\prime} M_{c, t}+\varepsilon_{i, c, t},
$$

such that $f_{i, c}$ is the firm-specific effect. We assume that the error terms, $\omega_{i, c, t}$ and $\varepsilon_{i, c, t}$, can be characterized by independently distributed random variables with mean zero and variance $\sigma_{i, c, t}^{2}$.

The above estimations assume exogeneity of the explanatory variables. This is consistent with the existing literature on corporate finance. However, if some of the right hand side variables were endogenously determined, we would need to use instruments. To control for potential endogeneity biases and to check the robustness of the results, we estimate instrumental variable models of equation (1), as the third alternative specification. 


\section{Data}

Our sample contains firm-level data from seven emerging economies: Argentina, Brazil, Mexico, Indonesia, Malaysia, South Korea, and Thailand. To compare the preliberalization period with the post-liberalization period, it is necessary to use more than one database. Data on firms' balance sheets come from two sources with some overlapping years, the corporate finance database of the International Finance Corporation (IFC) and Worldscope. IFC has complete data for the 1980s and early 1990s; Worldscope has a large data set for the 1990s.

The complete data set comprises annual balance sheet data of publicly traded firms, from 1980 to 1999 . The pooled data set contains about 700 firms. This is the number of firms that remain in the sample after removing financial firms, outliers, firms that data set for less than three years, and firms with incompatible time series (due to the use of two sources). For each country, the data set contains the following number of firms and time periods: Argentina, 70, 1988 to 1999; Brazil, 102, 1985 to 1998; Indonesia, 72, 1989 to 1998; Malaysia, 111, 1983 to 1998 ; Mexico, 48, 1981 to 1998; South Korea, 94, 1980 to 1998; and Thailand, 189, 1980 to 1999.

The data set includes detailed information on the financial structure of firms, but it does not include sources and uses-of-funds statements. We exclude from the sample financial firms and banks, because they do not report information on the maturity structure of their debt and we are particularly interested in studying maturity.

To measure financial integration at the firm level, we construct indicators of access to international bond and equity markets. We use data from the Bank of New 
York, Euromoney, and JP Morgan (1999), which have a complete list of international bond issues, equity issues, equity cross listing, and depositary receipt programs.

To measure financial liberalization, we use a dummy variable, following the stock market liberalization dates reported in Bekaert and Harvey (2000). The liberalization years for each country are Argentina 1991, Brazil 1990, Mexico 1993, Indonesia 1992, Malaysia 1992, South Korea 1993, and Thailand 1990. Similar liberalization dates are used in other papers, like in Henry (2000a and 2000b). We believe that the variable we use captures more general financial liberalization processes. As mentioned in the introduction, stock market liberalization takes place jointly with other financial liberalization measures. In fact, we obtained similar results using alternative variables, which account for more general measures of financial liberalization.

To measure the degree of domestic financial development, we use the sum of the stock market capitalization and liabilities of the banking sector, as a percentage of GDP, following Beck, Demirgüç-Kunt, and Levine (2000). We compute the interaction of this variable with the financial liberalization dummy. The data come from the World Bank's World Development Indicators.

Table 1 displays summary statistics of the data for East Asia and Latin America using different time periods. The mean debt equity ratio for the entire sample is 1.896 . Short-term debt represents on average 70 percent of total debt; the mean retained earning over total liabilities is 0.311 . When comparing the $1980 \mathrm{~s}$ and the $1990 \mathrm{~s}$, the data show some differences, although they do not appear to be very large. For example, the means of both debt-equity and long-term debt-equity ratios decrease during the 1990s. When 
comparing East Asia and Latin America, there are more differences in the data. East Asian firms are more levered than Latin American companies. The mean debt-equity and long-term debt-equity ratios are 2.383 and 0.716 in East Asia, while they are 0.751 and 0.297 in Latin America.

\section{Pooled estimates}

This section presents the econometric results of the pooled estimates, which are displayed in Table 2. We first describe the effects of firms' characteristics on financial structure, to compare our results with the existing literature. Second, we describe the macroeconomic effects on financial structure. Third, we analyze how access to international financial markets affects financing choices.

\section{A. Firms' characteristics}

The results show that the variable size of firms, captured by the log of net fixed assets, is statistically significant in the models for long-term debt and the maturity structure of debt. Larger firms have a higher level of long-term debt and a lower proportion of short-term debt. This suggests that large firms have better access to credit markets than small firms do.

The variable related to the tangibility of assets, net fixed assets over total assets, is statistically significant. Large tangible assets are associated with lower debt-equity ratios, but not with long-term debt. At the same time, large tangible assets are related to a longer debt maturity structure. This effect seems to takes place through a reduction in short-term debt, since the tangibility of assets is not statistically significant in the equation for long-

\footnotetext{
${ }^{10}$ Note that data on retained earnings for Mexican firms are not available.
} 
term debt. The finding on tangibility of assets supports the argument by Morris (1976) according to which firms match the maturity of assets and liabilities. To reduce the probability of liquidity problems, firms with larger fixed assets need a longer maturity structure.

The variable profits over total assets is statistically significant. More profits are associated with lower debt-equity ratios. Also, higher profits are related to a shorter debt maturity structure, suggesting that long-term debt shrinks more than short-term debt. Additionally, higher profits are positively related to the level of internal financing (retained earnings over total debt). The results are consistent with the pecking order hypothesis. Higher profits shifts the financing choices towards internal financing, such that retained earnings finance investment projects, avoiding the market undervaluation of firms' securities. The above results are comparable and consistent with the existing literature; see Demirgüç-Kunt and Maksimovic (1996) and Booth, Aivazian, DemirgüçKunt, and Maksimovic (2001).

The estimations suggest that tradable producers have lower long-term debt. The maturity structure of tradable producers is tilted towards the short-term, relative to nontradable producers. These are new results; they have not been tested before in the literature. Given that tradable producers can create international collateral, they are less vulnerable to domestic financial crises. Then, following Diamond (1991), tradable producers are expected to be less concerned about liquidity risk and might prefer a shorter maturity structure. 


\section{B. Financial liberalization and crises}

The results show that financial liberalization is statistically significant in the estimations of financing choices. First, the ratio of long-term debt to equity is lower after financial liberalization. Second, as economies become more liberalized, the maturity structure shifts to the short term.

Financial liberalization does not seem to lead to higher debt-equity ratios. Debt might increase after financial liberalization, but the evidence does not support an increase of debt relative to equity. Perhaps both debt and equity are increasing as more financing opportunities come about. By focusing on debt relative to equity, the insignificant coefficient does not seem consistent with the claim that financial opening leads to overborrowing.

The development and growing importance of equity financing during the 1990s can help explain why we find a declining long-term debt-equity ratio and an insignificant coefficient for debt over equity. Financial liberalization in the 1990s differs from liberalization programs of the previous decade. Portfolio flows and FDI now play a crucial role in international capital markets. Moreover, globalization could have reduced the cost of equity capital, which in turn could have helped with the development of equity markets. Stulz (1999), among others, explains how globalization reduces the cost of equity capital. He argues that globalization can reduce the discount rate that investors apply to cash flows generated by equity investment. Stulz also explains that globalization

\footnotetext{
${ }^{11}$ As a caveat, consider that these estimates only cover non-financial firms and that financial liberalization took place in the early 1990s. Debt-equity ratios could have increased during the mid 1990s and mostly in financial firms.
} 
could improve corporate governance, making it less expensive for firms to raise funds in capital markets.

The existing literature on corporate finance provides arguments that can explain a shortening debt maturity structure after financial liberalization. Myers (1977) shows that shareholders might decide to underinvest to avoid passing the proceeds of future projects to bondholders, when the value of firms depends on growth opportunities. Myers claims that, alternatively, a shorter debt maturity structure can avoid sub-optimal investment decisions. Firms from emerging economies typically face new growth opportunities when financial liberalization takes place. In fact, large current account deficits in emerging economies are usually interpreted as evidence of new investment in projects with highexpected returns. To take advantage of these opportunities, firms might decide to undertake short-term borrowing.

Existing arguments in the international finance literature also support the shortening in maturity after financial liberalization. As economies open, low international interest rates and expectations of government bailouts in the case of crises can make it optimal for domestic borrowers to seek international financing. On the other hand, asymmetric information between foreign lenders and domestic borrowers and inadequate prudential regulation and taxes can provide incentives for lenders to limit their financing to the short term. This situation might lead to increasing short-term debt when economies

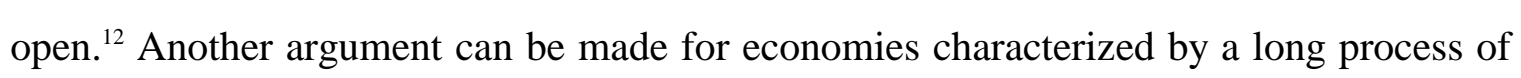

\footnotetext{
${ }^{12}$ For a discussion, see for example Furman and Stiglitz (1998), Rodrik and Velasco (1999), and Jeanne (2000).
} 
growth without productivity gains. ${ }^{\text {G }}$ Factor intensive growth increases the likelihood of facing diminishing returns in the long run. Anticipating this, newly available international financing due to financial liberalization will mainly take the form of short-term debt, shifting the debt maturity structure. ${ }^{\text {L }}$

Financial crises have a significant effect on leverage ratios. Debt-equity ratios increased during the Asian crisis. But leverage ratios did not increase during the Mexican crisis, which was confined to the first quarter of 1995 and involved mainly Mexico and Argentina. The increase in leverage is not driven by the decline in stock market prices, because we work with the book value of equity. High interest rates during crises likely explain the increase in leverage ratios. Debt contracts with floating rates might have increased the level of long-term debt.

\section{Financial liberalization and domestic financial development}

In the previous section, we studied the effect of financial liberalization on financing choices. However, countries with varying degrees of domestic financial development might be affected differently by financial liberalization. Firms from countries with developed domestic financial systems are expected to see relatively few changes after gaining access to world capital markets. Whereas, companies from countries with underdeveloped domestic financial markets likely face more changes in their financing opportunities as financial sectors are liberalized.

\footnotetext{
${ }^{13}$ This is the case of some East Asian economies in the last two decades; see Krugman (1994).

${ }^{14}$ Claessens, Djankov, and Lang (1998) argue that low profitability in some of the East Asian economies forced firms to look for external financing during the decade previous to the financial crisis, with short-term debt playing an important role.
} 
We test whether domestic financial development matters, using the interaction of the variables domestic financial development and financial liberalization. This interaction measures the effect of financial liberalization on firms' financing choices, according to the degree of domestic financial development.

The results show that countries with more developed domestic financial systems are less sensitive to liberalization. The interaction variable, as expected, has the opposite sign to the liberalization variable. In other words, the negative relation between liberalization and long-term debt is stronger in countries with less developed domestic financial systems. Similarly, the maturity structure moves to the short term to a lesser degree in countries with deeper financial markets.

\section{Access to international markets}

The financial liberalization variable captures the impact of financial integration for the average firm. But this variable does not identify the effect of the actual participation in international financial markets. To study this effect, we investigate how firms' financial structures change when they issue bonds or trade equity in international markets. Firms with access to international capital markets might have different financing choices than firms that fund investment through domestic markets.

The results show that access to international equity markets is associated with better access to long-term debt and, consequently, with a longer debt maturity structure. This result implies that participation in international equity markets through cross listing or depositary receipts could simplify firms' access to debt markets. Access to equity markets might differentiate firms, acting as a signal of credit worthiness. 
Similarly, access to international bond markets is positive and statistically significant in the case of three variables. Access to international bond markets is positively associated with debt over equity and long-term debt over equity. More importantly, access to bond markets extends the maturity structure of debt. Capital markets in developed countries typically have better financial institutions and are more liquid than markets in emerging economies. These characteristics tend to promote deep markets for long-term financing. The evidence suggests that firms from emerging economies benefit from accessing international markets, where they obtain long-term financing.

In sum, the financial liberalization variable and the variable capturing access to international capital markets suggest that financial integration does not seem to have a uniform effect across firms. On the one hand, access to international capital markets during the 1990s is associated with an extended maturity structure for firms that participate in these markets. On the other hand, the maturity structure shrinks for the average firm. These two findings suggest that firms constrained to local financial markets are the ones relying more on short-term debt.

\section{Alternative estimates}

In this section, we report alternative estimates to show the sensitivity of the results presented above. First, we obtain separate estimates for East Asia and Latin America. Second, we calculate within estimates. Finally, we use instrumental variables. 


\section{A. Regional estimates}

Four points are worth mentioning when comparing pooled results with regional estimates. These points focus on the differences between East Asian and Latin American estimates, which are displayed in Tables 3 and 4. First, firm specific characteristics seem to be more relevant in East Asia than in Latin America. Some variables that turn out statistically significant in East Asia are not significant in Latin America. For example, larger firms obtain more long-term debt and rely less on retained earnings only in East Asia. Also, tradable producers have less long-term debt and a shorter debt maturity structure, while tradable producers rely more on internal financing in East Asia.

Second, the financial liberalization process seems to have more significant effects in Latin America. Only in this region, the financial liberalization variable is statistically significant in the equations that explain total debt and long-term debt. This variable takes

a negative sign, meaning that leverage decreases after financial liberalization. Changes in debt-equity ratios can be reflecting not only changes in debt but also changes in equity. In fact, Latin America received record levels of equity investment in the 1990s, what might be explaining the results.

Third, access to international bond markets is associated with an increased debtequity ratio in Latin America, but not in East Asia. Fourth, the Asian crisis had significant effects both in East Asia and Latin America. As expected, the point estimates suggest that the Asian crisis had a much stronger impact in East Asia, despite its spillover effects to Latin America. 


\section{B. Within estimates}

The within estimates allow us to analyze whether the results obtained in the pooled estimates are mainly driven by the cross-sectional variation. Table 5 shows that the results hold within firms for most of the variables. With respect to the variables related to access, when firms access the international bond and equity markets, they increase their long-term debt and extend the maturity of their debt. The previous results related to financial liberalization, financial development, and crises also hold for the within estimators in most cases. Thus, the results from the previous sections are not only driven by differences between firms with and without access to international capital markets.

One result is new in the within estimates. The maturity structure shifts to the long run both during the Mexican and Asian crises. This result might be the combination of two effects. Firms with outstanding long-term debt face higher floating-rates during crises, increasing the level of long-term debt, as the estimates show. At the same time, firms might find it difficult to roll over their short-term debt contracts during crises.

\section{Instrumental variables}

Endogenous explanatory variables could bias the above results. In the event of endogeneity, it would likely be caused by the explanatory variables with cross-firm variation; macro variables are more likely to be exogenous. In particular, the variable capturing access to international bond markets might be endogenous, since it could be easier for firms with a certain financial structure to issue bonds internationally. 
To study the sensitivity of the results to potential endogeneity biases, we use the following instruments. In the case of the variables with continuous values and the variable access to equity markets, we use lagged values of the same variables as instruments. We work with two lags, to avoid cases for which there might be first-order autocorrelation of the residuals. This technique assumes that past values of the explanatory variables are uncorrelated with the contemporaneous error term. At the same time, past values of the explanatory variables should be correlated with contemporaneous values of the explanatory variables.

In the case of the variable access to bond markets, past values of the dummy variables are not suitable instruments because of their low correlation with contemporaneous values. Therefore, we construct an instrument that indicates whether capital markets are "open" for the country in which the firm resides. The instrument takes the value one if two conditions are fulfilled. First, markets are "open" for the country, in the sense that at least one firm from that country issues bonds in international capital markets during that period. Second, the firm is an "international" firm, in the sense that the firm was able to issue international bonds at least once in the sample period. Otherwise, the variable takes the value zero. This variable seems to be a valid instrument, given that the degree of market openness tends to be uncorrelated with the firm-level error term and, at the same time, it is correlated with the firm's access to international bond markets.

The instrumental variable estimates, displayed in Table 6, suggest that the previous results seem to be robust to endogeneity biases. The firm characteristics that are 
statistically significant in the pooled estimates mostly remain significant and with the same sign when we use instrumental variables. Something similar occurs for the variables related to financial liberalization. Access to international bond markets is positively related to a higher long-term debt-equity ratio and to a longer debt maturity structure. Access to international equity markets is related to higher leverage and long-term debt and to a longer debt maturity structure.

\section{Conclusions}

The process of financial globalization has attracted much attention. Some argue that globalization is beneficial, providing new investment and financing opportunities. Others claim that globalization can lead to overborrowing, higher vulnerabilities, exposure to volatile international markets, and eventually crises. Even though the debate is intense, only partial aspects of globalization have been analyzed.

This paper studied a new and important aspect of the globalization process by focusing on balance sheets. The paper shed new light on the behavior of firms' financing choices when countries integrate financially with world markets. The paper focused on non-financial firms from East Asia and Latin America. These regions have been integrating rapidly with the world economy and were hit by recent crises. Using a firmlevel panel, the paper studied the behavior of leverage ratios, debt maturity, and the choice between external and internal financing when economies become financially liberalized and when firms access international capital markets. To our knowledge, this 
type of evidence has not been previously examined and complements well the evidence found using aggregate data.

The paper showed that the globalization of financial markets has significant effects on firms' financing choices. The conclusions and new results from this paper can be summarized as follows.

First, debt relative to equity does not tend to increase after financial liberalization. In fact, debt-equity ratios tend to decrease in Latin America, perhaps due to the rapid development of equity markets in the 1990s. The evidence does not support the view that liberalization drives the economy to overborrowing if one concentrates on debt relative to equity.

Second, the results suggest that financial liberalization is associated with a shorter debt maturity structure. This effect is important in light of the arguments raised in recent work, suggesting that short-term debt maturity can play a crucial role in financial crises. What remains to be explained is why short-term debt increases after liberalization. Perhaps, foreign investors with inferior information are willing to lend only short term, once they gain access to previously closed markets. Given that financial liberalization is associated with shorter debt maturity, the evidence supports the claim that liberalization policies should be accompanied by strengthened prudential regulation to prevent maturity mismatches.

Third, the evidence indicates that firms from emerging economies with more developed domestic financial systems are less affected by financial liberalization. This implies that developed domestic financial sectors might provide similar financial 
instruments to the ones obtained abroad, what is particularly important for firms with no access to foreign financing. Moreover, if there exist any negative effects of financial liberalization, countries with more developed domestic markets should be less concerned about opening up their financial systems. If financial liberalization yields positive effects, countries with less developed financial sectors will be the ones benefiting the most.

Fourth, the data suggest that firms with access to international financial markets expand their financing opportunities. Firms with access to international bond markets increase their long-term debt, extending their debt maturity structure. Firms with access to international equity markets also increase their long-term debt and extend their debt maturity structure, as if access to international equity markets were a signal to access international debt markets.

Overall, the results show that firms with access to international capital markets extend their debt maturity, while the average firm reduces its maturity structure with financial liberalization. This suggests that globalization probably has uneven effects; firms that do not participate in international markets are likely increasing their short-term financing liabilities. In future work, it would be interesting to study in detail how firms confined to domestic financial markets are affected when a group of domestic firms go global.

Finally, leverage ratios tend to increase and the maturity structure extends during crisis times. Higher interest rates are likely behind the increase in debt-equity ratios. Higher floating rates on long-term debt and non-renewal of short-term debt contracts probably explain the change in maturity structure, given that issues of international and 
domestic bonds decreased during the crisis years. This is important because higher future debt payments tend to slow down the recovery after crises. 


\section{References}

Alexander, G., Eun, C., Janakiramanan, S., 1987, Asset pricing and dual listing on foreign capital markets: a note, Journal of Finance, 42, 151-58.

Alexander, G., Eun, C., Janakiramanan, S., 1998, International listings and stock returns: some empirical evidence, Journal of Financial and Quantitative Analysis, 23, 13551.

Beck, T., Demirgüç-Kunt, A., Levine, R., 2000, A New Database on Financial Development and Structure, forthcoming in World Bank Economic Review.

Bekaert, G., Harvey C., 2000, Foreign speculators and emerging equity markets, Journal of Finance, 55, 562-613.

Booth, L., Aivazian, V., Demirgüç-Kunt, A., and Maksimovic, V., 2001, Capital structures in developing countries, Journal of Finance, 56:1, 87-130.

Caballero, R., Krishnamurthy A., 1998, Emerging market crises: An asset markets perspective, NBER Working Paper No. 6843.

Claessens, S., Djankov, S., Lang, L., 1998, Corporate growth, financing, and risks in the decade before East Asia's financial crisis, Policy research working paper 2017, World Bank.

Demirgüç-Kunt, A., Maksimovic, V., 1996, Stock market development and financing choices of firms, World Bank Economic Review 10, 341-369.

Diamond, D.W., 1991, Debt maturity structure and liquidity risk, Quarterly Journal of Economics, 106, 709-737.

Domowitz, I., Glen, J., Madhavan, A., 1998, International Cross-Listing and Order Flow Migration: Evidence from an Emerging Market, Journal of Finance, 53:6, 20012027.

Errunza, V., 1999, Foreign Portfolio Equity Investments in Economic Development, forthcoming in the Review of International Economics.

Errunza, V., Miller, D., 2000, Market Segmentation and the Cost of Capital in International Equity Markets, forthcoming in the Journal of Financial and Quantitative Analysis.

Foerster, S., Karolyi A., 1999, The effects of market segmentation and investor recognition on asset prices: evidence form foreign stocks listing in the United States, Journal of Finance, 54:3, 981-1013.

Furman, J., Stiglitz, J., 1998, Economic Crises: Evidence and Insights from East Asia, Brookings Papers on Economic Activity, 2:1-114.

Gallego, F., Loayza N., 2000, Financial structure in Chile, manuscript, Central Bank of Chile.

Hargis, K., Ramanlal P., 1998, When does internationalization enhance the development of domestic stock markets? Journal of Financial Intermediation, Vol. 7, 263-292.

Henry, P., 2000a, Stock market liberalization, economic reform, and emerging market equity prices, Journal of Finance, 55, 529-564.

Henry, P., 2000b, Do stock market liberalizations cause investment booms? Journal of Financial Economics, 58, 301-334. 
Jaramillo, F., Schiantarelli, F., 1996, Access to long-term debt and effects on firms' performance: Lessons from Ecuador, manuscript, Boston College.

Jeanne, O., 2000, Debt maturity and the global financial architecture. CEPR Discussion Paper No. 2520.

JP Morgan, 1999, Emerging markets debt directory.

Kaminsky, G., Reinhart, C., 1999, The twin crises: The causes of banking and balance-ofpayments problems, American Economic Review, 89, 473-500.

Kim, E., Singal, V., 2000, Stock market openings: experience of emerging economies, Journal of Business, 73, 1, 25-66.

Krugman, P., 1994, The Myth of Asia's Miracle, Foreign Affairs.

Krugman, P., 1999, Balance sheets, the transfer problem, and financial crises, manuscript prepared for the festchrift volume in honor of Robert Flood

McKinnon, R., Pill, H., 1997, Credible economic liberalizations and overborrowing, American Economic Review, 87, 2, 189-93.

Miller, D., 1999, The market reaction to international cross-listings: evidence from depositary receipts, Journal of Financial Economics, 51, 103-23.

Morris, J., 1976, On corporate debt maturity strategies, Journal of Finance, 31, 1, 29-37.

Myers, S., 1977, Determinants of corporate borrowing, Journal of Financial Economics, $5,2,147-75$.

Myers, S., 1984, Capital structure puzzle, Journal of Finance, 39, 3, 575-92.

Myers, S., Majluf, N., 1984, Corporate financing and investment decisions when firms have information that investors do not have, Journal of Financial Economics, 13, 187-221.

Obstfeld, M., 1998, The global capital market: benefactor or menace? Journal of Economic Perspectives, Vol. 12, Fall, 9-30.

Rajan, R., Zingales, L., 1995, What Do We Know about Capital Structure? Some Evidence from International Data, Journal of Finance, 50, 5, 1421-1460.

Rodrik, D., Velasco, A., 1999, Short-Term Capital Flows, NBER Working Paper No. 7364.

Schiantarelli, F., Srivastava, V., 1996, Debt maturity and firm performance: A panel study of Indian public limited companies, manuscript, Boston College.

Stapleton, R., Subrahmanyam, M., 1977, Market Imperfections, Capital Market Equilibrium, and Corporate Finance, Journal of Finance, 32, 2, 307-19.

Stulz, R., 1999, Globalization of equity markets and the cost of capital, The Ohio State University, Dice Center, Working Paper 99-1. 
Table 1

\section{Summary Statistics}

The table reports summary statistics for the following ratios: debt/equity, long-term debt/equity, short-term debt/total debt ratio, and retained earnings/total liabilities. The first two ratios represent the firms' leverage, the third ratio captures the maturity structure of the debt, while the fourth ratio is a measure of internal financing. The first three panels contain summary statistics of the pooled data (East Asia and Latin America) for different sample periods.

\begin{tabular}{|c|c|c|c|c|}
\hline \multirow[b]{2}{*}{ Explanatory Variables } & \multicolumn{4}{|c|}{ Dependent Variables } \\
\hline & Debt / Equity & $\begin{array}{c}\text { Long-term debt } \\
\text { / Equity }\end{array}$ & $\begin{array}{c}\text { Short-term debt } \\
\text { / Total debt }\end{array}$ & $\begin{array}{c}\text { Retained earnings } / \\
\text { Total liabilities } \\
\end{array}$ \\
\hline \multirow[b]{2}{*}{ Mean } & \multicolumn{4}{|c|}{ 1980s and 1990s } \\
\hline & 1.896 & 0.591 & 0.703 & 0.311 \\
\hline \multirow{3}{*}{$\begin{array}{l}\text { Stantard deviation } \\
\text { Number of observations }\end{array}$} & 7.943 & 1.324 & 0.216 & 8.618 \\
\hline & 6,133 & 6,133 & 6,133 & 5,796 \\
\hline & \multicolumn{4}{|c|}{ 1980s } \\
\hline & 2.095 & 0.686 & 0.699 & 0.170 \\
\hline \multirow{3}{*}{$\begin{array}{l}\text { Stantard deviation } \\
\text { Number of observations }\end{array}$} & 2.949 & 1.309 & 0.209 & 0.373 \\
\hline & 2,142 & 2,142 & 2,142 & 2,055 \\
\hline & \multicolumn{4}{|c|}{$1990 \mathrm{~s}$} \\
\hline & 1.789 & 0.540 & 0.706 & 0.388 \\
\hline \multirow{3}{*}{$\begin{array}{l}\text { Stantard deviation } \\
\text { Number of observations }\end{array}$} & 9.605 & 1.329 & 0.191 & 10.724 \\
\hline & 3,991 & 3,991 & 3,991 & 3,741 \\
\hline & \multicolumn{4}{|c|}{ East Asia, 1980s and 1990s } \\
\hline \multirow{4}{*}{$\begin{array}{l}\text { Mean } \\
\text { Stantard deviation } \\
\text { Number of observations }\end{array}$} & 2.383 & 0.716 & 0.716 & 0.147 \\
\hline & 9.408 & 1.433 & 0.206 & 0.419 \\
\hline & 4,301 & 4,301 & 4,301 & 4,443 \\
\hline & \multicolumn{4}{|c|}{ Latin America, 1980s and 1990s } \\
\hline Mean & 0.751 & 0.297 & 0.673 & 0.848 \\
\hline Stantard deviation & 1.236 & 0.962 & 0.235 & 17.816 \\
\hline Number of observations & 1,832 & 1,832 & 1,832 & 1,353 \\
\hline
\end{tabular}


Table 2

Pooled Estimates

The table reports pooled panel results for the following ratios: debt/equity, long-term debt/equity, short-term debt/total debt ratio, and retained earnings/total liabilities. The first two ratios represent the firms' leverage, the third ratio captures the maturity structure of the debt, while the fourth ratio is a measure of internal financing. Standard errors are robust, using the White correction for heteroskedasticity. Thailand is the base country. T-statistics are in parenthesis.

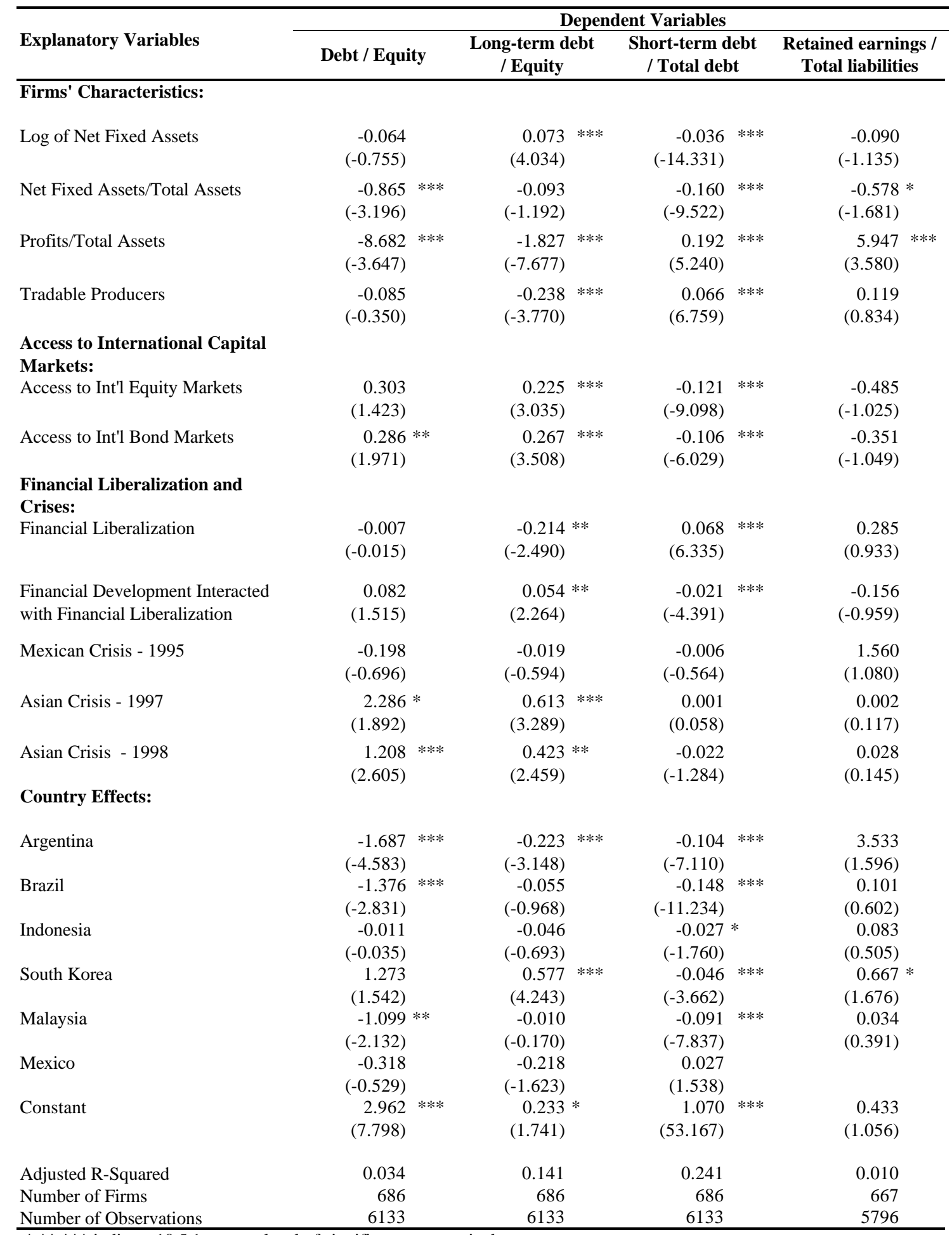

$*, * *, * * *$ indicate $10,5,1$ percent level of significance respectively. 
Table 3

\section{Pooled Estimates - East Asia}

The table reports pooled panel results for East Asian countries, for the following ratios: debt/equity, long-term debt/equity, short-term debt/total debt ratio, and retained earnings/total liabilities. The first two ratios reprsent the firms' leverage, the third ratio captures the maturity structure of the debt, while the fourth ratio is a measure of internal financing. Standard errors are robust, using the White correction for heteroskedasticity. Thailand is the base country. Tstatistics are in parenthesis.

\begin{tabular}{|c|c|c|c|c|}
\hline \multirow[b]{2}{*}{ Explanatory Variables } & \multicolumn{4}{|c|}{ Dependent Variables } \\
\hline & Debt / Equity & $\begin{array}{l}\text { Long-term debt } \\
\text { / Equity }\end{array}$ & $\begin{array}{c}\text { Short-term debt } \\
\text { / Total debt }\end{array}$ & $\begin{array}{c}\text { Retained earnings / } \\
\text { Total liabilities } \\
\end{array}$ \\
\hline \multicolumn{5}{|l|}{ Firms' Characteristics: } \\
\hline Log of Net Fixed Assets & $\begin{array}{r}-0.068 \\
(0.631)\end{array}$ & $\begin{array}{l}0.130 * * * \\
(5.1386)\end{array}$ & $\begin{array}{l}-0.043 * * * \\
(-11.697)\end{array}$ & $\begin{array}{l}-0.031 * * * \\
(-5.189)\end{array}$ \\
\hline Net Fixed Assets/Total Assets & $\begin{array}{l}-0.990 * * * \\
(-2.971)\end{array}$ & $\begin{array}{l}-0.194 * * \\
(-2.069)\end{array}$ & $\begin{array}{l}-0.132 * * * \\
(-7.488)\end{array}$ & $\begin{array}{r}-0.047 \\
(-1.503)\end{array}$ \\
\hline Profits/Total Assets & $\begin{array}{l}-13.853 * * * \\
(-2.914)\end{array}$ & $\begin{array}{l}-2.241 * * * \\
(-4.926)\end{array}$ & $\begin{array}{l}0.203 * * * \\
(3.817)\end{array}$ & $\begin{array}{l}2.470 \text { *** } \\
(12.951)\end{array}$ \\
\hline Tradable Producers & $\begin{array}{r}0.040 \\
(0.124)\end{array}$ & $\begin{array}{l}-0.275 * * * \\
(-3.928)\end{array}$ & $\begin{array}{l}0.073 * * * \\
(7.110)\end{array}$ & $\begin{array}{l}0.026 * * * \\
(2.848)\end{array}$ \\
\hline \multicolumn{5}{|l|}{$\begin{array}{l}\text { Access to International Capital } \\
\text { Markets: }\end{array}$} \\
\hline Access to Int'l Equity Markets & $\begin{array}{r}0.284 \\
(0.769)\end{array}$ & $\begin{array}{l}0.289 * * * \\
(2.608)\end{array}$ & $\begin{array}{l}-0.108 * * * \\
(-6.188)\end{array}$ & $\begin{array}{r}0.118 \\
(1.261)\end{array}$ \\
\hline Access to Int'l Bond Markets & $\begin{array}{r}0.112 \\
(0.473)\end{array}$ & $\begin{array}{l}0.294 * * \\
(2.501)\end{array}$ & $\begin{array}{l}-0.083 * * * \\
(-3.513)\end{array}$ & $\begin{array}{r}-0.015 \\
(-0.705)\end{array}$ \\
\hline \multicolumn{5}{|l|}{$\begin{array}{l}\text { Financial Liberalization and } \\
\text { Crises: }\end{array}$} \\
\hline Financial Liberalization & $\begin{array}{r}0.812 \\
(0.788)\end{array}$ & $\begin{array}{r}0.087 \\
(0.578)\end{array}$ & $\begin{array}{l}0.060 * * * \\
(4.323)\end{array}$ & $\begin{array}{r}0.016 \\
(0.876)\end{array}$ \\
\hline $\begin{array}{l}\text { Financial Development Interacted } \\
\text { with Financial Liberalization }\end{array}$ & $\begin{array}{r}-0.174 \\
(-0.525)\end{array}$ & $\begin{array}{r}-0.062 \\
(-1.442)\end{array}$ & $\begin{array}{l}-0.017 * * * \\
(-2.900)\end{array}$ & $\begin{array}{r}0.007 \\
(0.824)\end{array}$ \\
\hline Mexican Crisis - 1995 & $\begin{array}{r}-0.222 \\
(-0.488)\end{array}$ & $\begin{array}{r}0.016 \\
(0.336)\end{array}$ & $\begin{array}{r}-0.005 \\
(-0.408)\end{array}$ & $\begin{array}{r}0.015 \\
(0.637)\end{array}$ \\
\hline Asian Crisis - 1997 & $\begin{array}{l}2.809 * \\
(1.717)\end{array}$ & $\begin{array}{l}0.766 * * * \\
(3.106)\end{array}$ & $\begin{array}{r}0.007 \\
(0.456)\end{array}$ & $\begin{array}{r}0.012 \\
(0.383)\end{array}$ \\
\hline Asian Crisis - 1998 & $\begin{array}{l}1.349 * \\
(1.959)\end{array}$ & $\begin{array}{l}0.514 * * \\
(1.961)\end{array}$ & $\begin{array}{r}-0.006 \\
(-0.262)\end{array}$ & $\begin{array}{r}0.026 \\
(0.718)\end{array}$ \\
\hline \multicolumn{5}{|l|}{ Country Effects: } \\
\hline Indonesia & $\begin{array}{r}-0.059 \\
(-0.225)\end{array}$ & $\begin{array}{l}-0.258 * * * \\
(-3.293)\end{array}$ & $\begin{array}{r}-0.005 \\
(-0.319)\end{array}$ & $\begin{array}{l}0.357 * * * \\
(7.986)\end{array}$ \\
\hline South Korea & $\begin{array}{r}2.015 * \\
(1.697)\end{array}$ & $\begin{array}{l}0.543 * * * \\
(3.208)\end{array}$ & $\begin{array}{l}-0.029 * * \\
(-1.980)\end{array}$ & $\begin{array}{l}0.265 * * * \\
(11.613)\end{array}$ \\
\hline Malaysia & $\begin{array}{r}-0.800 \\
(-1.161)\end{array}$ & $\begin{array}{l}0.350 * * * \\
(3.849)\end{array}$ & $\begin{array}{l}-0.119 * * * \\
(-7.698)\end{array}$ & $\begin{array}{r}-0.027 \\
(-1.088)\end{array}$ \\
\hline Constant & $\begin{array}{l}3.006 * * * \\
(4.762)\end{array}$ & $\begin{array}{r}-0.316 \\
(-1.572)\end{array}$ & $\begin{array}{r}1.106 \\
(39.103)\end{array}$ & $\begin{array}{l}0.159 * * * \\
(3.233)\end{array}$ \\
\hline Adjusted R-Squared & 0.030 & 0.147 & 0.249 & 0.232 \\
\hline Number of Firms & 466 & 466 & 466 & 503 \\
\hline Number of Observations & 4301 & 4301 & 4301 & 4443 \\
\hline
\end{tabular}

$*, * *, * * *$ indicate $10,5,1$ percent level of significance respectively. 


\section{Table 4}

\section{Pooled Estimates - Latin America}

The table reports pooled panel results for Latin American countries, the following ratios: debt/equity, long-term debt/equity, short-term debt/total debt ratio, and retained earnings/total liabilities. The first two ratios reprsent the firms' leverage, the third ratio captures the maturity structure of the debt, while the fourth ratio is a measure of internal financing. Standard errors are robust, using the White correction for heteroskedasticity. Mexico is the base country. T-statistics are in parenthesis.

\begin{tabular}{|c|c|c|c|c|}
\hline \multirow{2}{*}{ 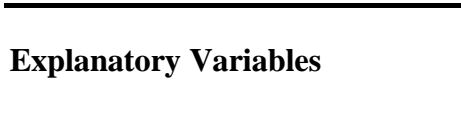 } & \multicolumn{4}{|c|}{ Dependent Variables } \\
\hline & Debt / Equity & $\begin{array}{c}\text { Long-term debt } \\
\text { Equity }\end{array}$ & $\begin{array}{c}\text { / Short-term debt } \\
\text { / Total debt }\end{array}$ & $\begin{array}{c}\text { Retained earnings / } \\
\text { Total liabilities }\end{array}$ \\
\hline \multicolumn{5}{|l|}{ Firms' Characteristics: } \\
\hline Log of Net Fixed Assets & $\begin{array}{r}0.039 \\
(1.229)\end{array}$ & $\begin{array}{r}0.040 \\
(1.560)\end{array}$ & $\begin{array}{l}-0.029 * * * \\
(-7.341)\end{array}$ & $\begin{array}{r}-0.309 \\
(-1.066)\end{array}$ \\
\hline Net Fixed Assets/Total Assets & $\begin{array}{l}-0.701 * * * \\
(-3.172)\end{array}$ & $\begin{array}{r}0.014 \\
(0.111)\end{array}$ & $\begin{array}{l}-0.215 * * * \\
(-4.197)\end{array}$ & $\begin{array}{l}-1.927 * \\
(-1.366)\end{array}$ \\
\hline Profits/Total Assets & $\begin{array}{l}-2.624 * * * \\
(-8.454)\end{array}$ & $\begin{array}{l}-1.296 * * * \\
(-6.636)\end{array}$ & $\begin{array}{l}0.182 * * * \\
(3.391)\end{array}$ & $\begin{array}{l}10.219 * * \\
(2.524)\end{array}$ \\
\hline Tradable Producers & $\begin{array}{r}-0.114 \\
(-1.069)\end{array}$ & $\begin{array}{r}-0.004 \\
(-0.082)\end{array}$ & $\begin{array}{r}-0.009 \\
(-0.278)\end{array}$ & $\begin{array}{r}0.805 \\
(0.652)\end{array}$ \\
\hline \multicolumn{5}{|l|}{$\begin{array}{l}\text { Access to International Capital } \\
\text { Markets: }\end{array}$} \\
\hline Access to Int'l Equity Markets & $\begin{array}{r}0.145 \\
(1.550)\end{array}$ & $\begin{array}{l}0.120 * \\
(1.722)\end{array}$ & $\begin{array}{l}-0.137 * * * \\
(-6.403)\end{array}$ & $\begin{array}{r}-1.780 \\
(-1.305)\end{array}$ \\
\hline Access to Int'l Bond Markets & $\begin{array}{l}0.195 * * \\
(2.310)\end{array}$ & $\begin{array}{l}0.145 * * * \\
(2.578)\end{array}$ & $\begin{array}{l}-0.124 * * * \\
(-4.514)\end{array}$ & $\begin{array}{r}-0.560 \\
(-0.629)\end{array}$ \\
\hline \multicolumn{5}{|l|}{$\begin{array}{l}\text { Financial Liberalization and } \\
\text { Crises: }\end{array}$} \\
\hline Financial Liberalization & $\begin{array}{l}-0.566 * * * \\
(-3.906)\end{array}$ & $\begin{array}{l}-0.363 * * * \\
(-3.383)\end{array}$ & $\begin{array}{l}0.113 * * * \\
(4.358)\end{array}$ & $\begin{array}{r}2.259 \\
(0.771)\end{array}$ \\
\hline $\begin{array}{l}\text { Financial Development Interacted } \\
\text { with Financial Liberalization }\end{array}$ & $\begin{array}{r}0.571 \\
(1.437)\end{array}$ & $\begin{array}{r}0.308 \\
(1.048)\end{array}$ & $\begin{array}{l}-0.136 * * * \\
(-2.584)\end{array}$ & $\begin{array}{r}-4.378 \\
(-0.682)\end{array}$ \\
\hline Mexican Crisis - 1995 & $\begin{array}{r}0.061 \\
(0.757)\end{array}$ & $\begin{array}{r}0.013 \\
(0.245)\end{array}$ & $\begin{array}{r}-0.001 \\
(-0.059)\end{array}$ & $\begin{array}{r}6.664 \\
(1.034)\end{array}$ \\
\hline Asian Crisis - 1997 & $\begin{array}{l}0.290 * * \\
(2.008)\end{array}$ & $\begin{array}{r}0.164 \\
(1.508)\end{array}$ & $\begin{array}{r}-0.012 \\
(-0.455)\end{array}$ & $\begin{array}{r}-0.883 \\
(-0.798)\end{array}$ \\
\hline Asian Crisis - 1998 & $\begin{array}{l}0.347 * \\
(1.908)\end{array}$ & $\begin{array}{l}0.208 * \\
(1.952)\end{array}$ & $\begin{array}{r}-0.031 \\
(-1.040)\end{array}$ & $\begin{array}{r}0.261 \\
(0.257)\end{array}$ \\
\hline \multicolumn{5}{|l|}{ Country Effects: } \\
\hline Argentina & $\begin{array}{r}0.010 \\
(0.066)\end{array}$ & $\begin{array}{r}0.020 \\
(0.157)\end{array}$ & $\begin{array}{l}-0.133 * * * \\
(-4.541)\end{array}$ & $\begin{array}{r}3.241 \\
(1.597)\end{array}$ \\
\hline Brazil & $\begin{array}{r}-0.083 \\
(-0.451)\end{array}$ & $\begin{array}{r}-0.076 \\
(-0.531)\end{array}$ & $\begin{array}{l}-0.137 * * * \\
(-4.245)\end{array}$ & \\
\hline Constant & $\begin{array}{r}1.243 \text { *** } \\
(3.253)\end{array}$ & $\begin{array}{r}0.165 \\
(0.557)\end{array}$ & $\begin{array}{r}1.128 \\
(20.509)\end{array}$ & $\begin{array}{r}1.483 \\
(1.309)\end{array}$ \\
\hline Adjusted R-Squared & 0.077 & 0.046 & 0.215 & 0.012 \\
\hline Number of Firms & 220 & 220 & 220 & 164 \\
\hline Number of Observations & 1832 & 1832 & 1832 & 1353 \\
\hline
\end{tabular}

$*, * *, * * *$ indicate $10,5,1$ percent level of significance respectively. 


\section{Table 5}

\section{Within Estimates}

The table reports within (or fixed effects) results for the following ratios: debt/equity, long-term debt/equity, short-term debt/total debt ratio, and retained earnings/total liabilities. The first two ratios reprsent the firms' leverage, the third ratio captures the maturity structure of the debt, while the fourth ratio is a measure of internal financing. Standard errors ar robust, using the White correction for heteroskedasticity. Thailand is the base country. T-statistics are in parenthesis.

\begin{tabular}{|c|c|c|c|c|}
\hline \multirow[b]{2}{*}{ Explanatory Variables } & \multicolumn{4}{|c|}{ Dependent Variables } \\
\hline & Debt / Equity & $\begin{array}{l}\text { Long-term debt } \\
\text { / Equity } \\
\end{array}$ & $\begin{array}{c}\text { Short-term debt } \\
\text { / Total debt }\end{array}$ & $\begin{array}{c}\text { Retained earnings / } \\
\text { Total liabilities } \\
\end{array}$ \\
\hline \multicolumn{5}{|l|}{ Firms' Characteristics: } \\
\hline Log of Net Fixed Assets & $\begin{array}{l}-0.121 * * \\
(-2.649)\end{array}$ & $\begin{array}{r}0.003 \\
(0.234)\end{array}$ & $\begin{array}{l}-0.020 * * * \\
(-7.455)\end{array}$ & $\begin{array}{r}-0.095 \\
(-1.301)\end{array}$ \\
\hline Net Fixed Assets/Total Assets & $\begin{array}{r}-0.060 \\
(-0.194)\end{array}$ & $\begin{array}{r}-0.048 \\
(-0.465)\end{array}$ & $\begin{array}{l}-0.077 \text { *** } \\
(-3.559)\end{array}$ & $\begin{array}{r}0.166 \\
(0.860)\end{array}$ \\
\hline Profits/Total Assets & $\begin{array}{l}-8.220 * * * \\
(-2.910)\end{array}$ & $\begin{array}{l}-1.559 * * * \\
(-5.888)\end{array}$ & $\begin{array}{l}0.198 * * * \\
(5.195)\end{array}$ & $\begin{array}{c}2.601 * \\
(1.798)\end{array}$ \\
\hline \multicolumn{5}{|l|}{$\begin{array}{l}\text { Access to International Capital } \\
\text { Markets: }\end{array}$} \\
\hline Access to Int'l Equity Markets & $\begin{array}{r}0.326 \\
(0.792)\end{array}$ & $\begin{array}{l}0.275^{* *} \\
(2.138)\end{array}$ & $\begin{array}{l}-0.053 * * * \\
(-3.242)\end{array}$ & $\begin{array}{r}-0.034 \\
(-0.231)\end{array}$ \\
\hline Access to Int'l Bond Markets & $\begin{array}{r}0.136 \\
(0.748)\end{array}$ & $\begin{array}{l}0.259 * * * \\
(3.512)\end{array}$ & $\begin{array}{l}-0.074 * * * \\
(-5.905)\end{array}$ & $\begin{array}{r}0.156 \\
(1.168)\end{array}$ \\
\hline $\begin{array}{l}\text { Financial Liberalization and } \\
\text { Crises: }\end{array}$ & & & & \\
\hline Financial Liberalization & $\begin{array}{r}0.108 \\
(0.290)\end{array}$ & $\begin{array}{l}-0.006 * \\
(-0.102)\end{array}$ & $\begin{array}{l}0.030 * * * \\
(3.120)\end{array}$ & $\begin{array}{r}0.021 \\
(0.197)\end{array}$ \\
\hline $\begin{array}{l}\text { Financial Development Interacted } \\
\text { with Financial Liberalization }\end{array}$ & $\begin{array}{r}0.085 \\
(0.591)\end{array}$ & $\begin{array}{l}0.021 * * * \\
(1.129)\end{array}$ & $\begin{array}{l}-0.016 * * * \\
(-3.958)\end{array}$ & $\begin{array}{r}-0.056 \\
(-0.800)\end{array}$ \\
\hline Mexican Crisis - 1995 & $\begin{array}{r}-0.057 \\
(-0.392)\end{array}$ & $\begin{array}{r}0.028 \\
(0.999)\end{array}$ & $\begin{array}{l}-0.018 * * \\
(-2.235)\end{array}$ & $\begin{array}{r}1.377 \\
(1.382)\end{array}$ \\
\hline Asian Crisis - 1997 & $\begin{array}{l}2.301 * * \\
(1.855)\end{array}$ & $\begin{array}{l}0.684 * * * \\
(3.802)\end{array}$ & $\begin{array}{r}-0.013 \\
(-1.408)\end{array}$ & $\begin{array}{r}0.187 \\
(0.816)\end{array}$ \\
\hline Asian Crisis - 1998 & $\begin{array}{l}1.367 \text { *** } \\
(3.580)\end{array}$ & $\begin{array}{l}0.459 \text { *** } \\
(3.071)\end{array}$ & $\begin{array}{l}-0.029 * * \\
(-2.189)\end{array}$ & $\begin{array}{r}0.317 \\
(1.577)\end{array}$ \\
\hline Adjusted R-Squared & 0.108 & 0.300 & 0.578 & 0.165 \\
\hline Chi-Hausman & 0.005 & 0.855 & $41.885 * * *$ & 0.022 \\
\hline Number of Firms & 686 & 686 & 686 & 667 \\
\hline Number of Observations & 6133 & 6133 & 6133 & 5796 \\
\hline
\end{tabular}

\footnotetext{
$*, * *, * * *$ indicate $10,5,1$ percent level of significance respectively.
} 
Table 6

\section{Instrumental Variable Estimates}

The table reports instrumental variables results for the following ratios: debt/equity, long-term debt/equity, short-term debt/total debt ratio, and retained earnings/total liabilities. The first two ratios reprsent the firms' leverage, the third ratio captures the maturity structure of the debt, while the fourth ratio is a measure of internal financing. Standard errors are robust, using the White correction for heteroskedasticity. Thailand is the base country. T-statistics are in parenthesis. Instruments are lagged explanatory variables of Firms' Characteristics (except the variable Tradable Producers), lagged values of the variable Access to Int'l Equity Markets, and an indicator of each country's access to international bond markets. See main text for description of the latter instrument.

\begin{tabular}{|c|c|c|c|c|}
\hline \multirow[b]{2}{*}{ Explanatory Variables } & \multicolumn{4}{|c|}{ Dependent Variables } \\
\hline & Debt / Equity & $\begin{array}{l}\text { Long-term debt } \\
\text { / Equity }\end{array}$ & $\begin{array}{c}\text { Short-term debt } \\
\text { / Total debt }\end{array}$ & $\begin{array}{c}\text { Ketamited } \\
\text { earnings / Total } \\
\text { liahilitios }\end{array}$ \\
\hline \multicolumn{5}{|l|}{ Firms' Characteristics: } \\
\hline Log of Net Fixed Assets & $\begin{array}{r}-0.018 \\
(-0.306)\end{array}$ & $\begin{array}{l}0.102 * * * \\
(5.474)\end{array}$ & $\begin{array}{l}-0.037 * * * \\
(-9.381)\end{array}$ & $\begin{array}{r}0.028 \\
(0.482)\end{array}$ \\
\hline Net Fixed Assets/Total Assets & $\begin{array}{l}-1.607 * * * \\
(-5.971)\end{array}$ & $\begin{array}{l}-0.267 * * \\
(-2.211)\end{array}$ & $\begin{array}{l}-0.182 * * * \\
(-8.604)\end{array}$ & $\begin{array}{r}-1.379 \\
(-1.435)\end{array}$ \\
\hline Profits/Total Assets & $\begin{array}{l}-16.518 * * * \\
(-5.054)\end{array}$ & $\begin{array}{l}-3.663 * * * \\
(-7.243)\end{array}$ & $\begin{array}{l}0.240 * * \\
(2.103)\end{array}$ & $\begin{array}{r}13.466 \\
(1.430)\end{array}$ \\
\hline Tradable Producers & $\begin{array}{r}0.163 \\
(0.530)\end{array}$ & $\begin{array}{l}-0.219 * * * \\
(-3.123)\end{array}$ & $\begin{array}{l}0.068 * * * \\
(5.937)\end{array}$ & $\begin{array}{r}0.006 \\
(0.060)\end{array}$ \\
\hline \multicolumn{5}{|l|}{$\begin{array}{l}\text { Access to International Capital } \\
\text { Markets: }\end{array}$} \\
\hline Access to Int'l Equity Markets & $\begin{array}{l}0.841 * * \\
(2.566)\end{array}$ & $\begin{array}{l}0.415 * * * \\
(3.575)\end{array}$ & $\begin{array}{l}-0.088 * * * \\
(-4.144)\end{array}$ & $\begin{array}{r}-0.576 \\
(-0.861)\end{array}$ \\
\hline Access to Int'l Bond Markets & $\begin{array}{r}0.648 \\
(1.575)\end{array}$ & $\begin{array}{l}0.284 * * \\
(2.047)\end{array}$ & $\begin{array}{l}-0.226 * * * \\
(-6.079)\end{array}$ & $\begin{array}{r}-1.888 \\
(-1.359)\end{array}$ \\
\hline \multicolumn{5}{|l|}{$\begin{array}{l}\text { Financial Liberalization and } \\
\text { Crises: }\end{array}$} \\
\hline Financial Liberalization & $\begin{array}{r}-0.263 \\
(-1.459)\end{array}$ & $\begin{array}{l}-0.242 * * * \\
(-3.216)\end{array}$ & $\begin{array}{l}0.056 * * * \\
(4.090)\end{array}$ & $\begin{array}{r}0.196 \\
(0.602)\end{array}$ \\
\hline $\begin{array}{l}\text { Financial Development Interacted } \\
\text { with Financial Liberalization }\end{array}$ & $\begin{array}{r}0.092 \\
(1.097)\end{array}$ & $\begin{array}{l}0.059 * * \\
(2.119)\end{array}$ & $\begin{array}{l}-0.015 * * \\
(-2.175)\end{array}$ & $\begin{array}{r}-0.173 \\
(-0.707)\end{array}$ \\
\hline Mexican Crisis - 1995 & $\begin{array}{r}-0.402 \\
(-1.130)\end{array}$ & $\begin{array}{r}-0.051 \\
(-1.491)\end{array}$ & $\begin{array}{r}-0.007 \\
(-0.574)\end{array}$ & $\begin{array}{r}1.514 \\
(1.010)\end{array}$ \\
\hline Asian Crisis - 1997 & $\begin{array}{r}0.808 \\
(1.607)\end{array}$ & $\begin{array}{l}0.386 * * * \\
(4.006)\end{array}$ & $\begin{array}{r}-0.006 \\
(-0.418)\end{array}$ & $\begin{array}{r}-0.107 \\
(-0.395)\end{array}$ \\
\hline Asian Crisis - 1998 & $\begin{array}{r}0.644 \\
(1.417)\end{array}$ & $\begin{array}{l}0.234 \text { *** } \\
(2.903)\end{array}$ & $\begin{array}{r}-0.022 \\
(-1.222)\end{array}$ & $\begin{array}{r}-0.200 \\
(-0.648)\end{array}$ \\
\hline \multicolumn{5}{|l|}{ Country Effects: } \\
\hline Argentina & $\begin{array}{l}-2.008 * * * \\
(-2.972)\end{array}$ & $\begin{array}{l}-0.209 * * \\
(-2.479)\end{array}$ & $\begin{array}{l}-0.091 \text { *** } \\
(-4.541)\end{array}$ & $\begin{array}{c}5.351 * \\
(1.676)\end{array}$ \\
\hline Brazil & $\begin{array}{l}-1.849 * * \\
(-2.307)\end{array}$ & $\begin{array}{r}-0.045 \\
(-0.528)\end{array}$ & $\begin{array}{l}-0.139 \text { **** } \\
(-7.893)\end{array}$ & $\begin{array}{r}0.773 \\
(1.473)\end{array}$ \\
\hline Indonesia & $\begin{array}{r}-0.186 \\
(-0.258)\end{array}$ & $\begin{array}{r}-0.063 \\
(-0.785)\end{array}$ & $\begin{array}{r}-0.002 \\
(-0.133)\end{array}$ & $\begin{array}{r}-0.669 \\
(-0.734)\end{array}$ \\
\hline South Korea & $\begin{array}{r}0.602 \\
(0.720)\end{array}$ & $\begin{array}{l}0.379 * * * \\
(3.914)\end{array}$ & $\begin{array}{l}-0.044 * * * \\
(-2.805)\end{array}$ & $\begin{array}{r}0.629 \\
(1.371)\end{array}$ \\
\hline Malaysia & $\begin{array}{c}-1.217 * \\
(-1.794)\end{array}$ & $\begin{array}{r}0.112 \\
(1.501)\end{array}$ & $\begin{array}{r}-0.101 \\
(-6.185)\end{array}$ & $\begin{array}{r}0.452 \\
(0.988)\end{array}$ \\
\hline Mexico & $\begin{array}{r}-1.237 \\
(-1.467)\end{array}$ & $\begin{array}{l}-0.414 \text { **** } \\
(-2.974)\end{array}$ & $\begin{array}{l}0.066 \text { *** } \\
(2.850)\end{array}$ & \\
\hline Constant & $\begin{array}{l}3.825 \text { *** } \\
(5.691)\end{array}$ & $\begin{array}{r}0.130 \\
(0.844)\end{array}$ & $\begin{array}{l}1.078 \text { *** } \\
(35.387)\end{array}$ & $\begin{array}{r}-0.372 \\
(-0.661)\end{array}$ \\
\hline Adjusted R-Squared & 0.031 & 0.178 & 0.240 & 0.011 \\
\hline Number of Firms & 686 & 686 & 686 & 667 \\
\hline Number of Observations & 4654 & 4654 & 4654 & 4482 \\
\hline
\end{tabular}




\section{DAVIDSON INSTITUTE WORKING PAPER SERIES - Most Recent Papers}

The entire Working Paper Series is available at: www.wdi.bus.umich.edu

CURRENT AS OF 9/21/01

\begin{tabular}{|c|c|c|}
\hline Publication & Authors & Date \\
\hline $\begin{array}{l}\text { No. } 388 \text { Globalization and Firms' Financing Choices: } \\
\text { Evidence from Emerging Economies }\end{array}$ & $\begin{array}{l}\text { Sergio Schmukler and Esteban } \\
\text { Vesperoni }\end{array}$ & May 2001 \\
\hline $\begin{array}{l}\text { No. } 387 \text { The Distributional Impacts of Indonesia's Financial Crisis on } \\
\text { Household Welfare: A "Rapid Response" Methodology }\end{array}$ & $\begin{array}{l}\text { Jed Friedman and James } \\
\text { Levinsohn }\end{array}$ & Sept. 2001 \\
\hline $\begin{array}{l}\text { No. } 386 \text { Corporate Financial Policies and Performance Prior to Currency } \\
\text { Crises }\end{array}$ & $\begin{array}{l}\text { Arturo Bris, Yrjö Koskinen, and } \\
\text { Vicente Pons }\end{array}$ & June 2001 \\
\hline No. 385 Ownership and Productive Efficiency: Evidence from Estonia & Derek C. Jones and Niels Mygind & Aug. 2001 \\
\hline No. 384 Institutional Determinants of Labor Reallocation in Transition & Tito Boeri and Katherine Terrell & June 2001 \\
\hline $\begin{array}{l}\text { No. } 383 \text { Deindustrialisation and Structural Change During the Post- } \\
\text { Communist Transition }\end{array}$ & $\begin{array}{l}\text { Tomasz Mickiewicz and Anna } \\
\text { Zalewska }\end{array}$ & June 2001 \\
\hline No. 382 Markets and Growth & Štěpán Jurajda and Janet Mitchell & July 2001 \\
\hline $\begin{array}{l}\text { No. } 381 \text { Labor Market Discrimination During Post-Communist } \\
\text { Transition: A Monopsony Approach to the Status of Latvia's Russian } \\
\text { Minority }\end{array}$ & Robert S. Chase & Sept. 2000 \\
\hline No. 380 Dollarization of Liabilities in Non-tradable Goods Sector & Frédéric Chabellard & June 2001 \\
\hline $\begin{array}{l}\text { No. } 379 \text { Lessons from the Russian Meltdown: The Economics of Soft } \\
\text { Legal Constraints }\end{array}$ & Enrico Perotti & Mar. 2001 \\
\hline No. 378 Effective Tax Rates in Transition & Vlad Ivanenko & May 2001 \\
\hline $\begin{array}{l}\text { No. } 377 \text { Some Explanations for Changes in the Distribution of } \\
\text { Household Income in Slovakia: } 1988 \text { and } 1996\end{array}$ & $\begin{array}{l}\text { Thesia Garner and Katherine } \\
\text { Terrell }\end{array}$ & May 2001 \\
\hline $\begin{array}{l}\text { No. } 376 \text { Competition and Enterprise Performance in Transition } \\
\text { Economies: Evidence from a Cross-country Survey }\end{array}$ & $\begin{array}{l}\text { Wendy Carlin, Steven Fries, } \\
\text { Mark Schaffer and Paul Seabright }\end{array}$ & May 2001 \\
\hline $\begin{array}{l}\text { No. } 375 \text { Why More is Actually Less: New Interpretations of China's } \\
\text { Labor-Intensive FDI }\end{array}$ & Yasheng Huang & May 2001 \\
\hline No. 374 Economic Fragmentation and FDI in China & Yasheng Huang & May 2001 \\
\hline $\begin{array}{l}\text { No. } 373 \text { Earnings Disparities in the Czech Republic: Evidence of the } \\
\text { Past Decade and Cross-National Comparison }\end{array}$ & Jiri Vecernik & May 2001 \\
\hline $\begin{array}{l}\text { No. } 372 \text { Economic Reform, Democracy and Growth During Post- } \\
\text { Communist Transition }\end{array}$ & Jan Fidrmuc & Mar. 2001 \\
\hline $\begin{array}{l}\text { No. } 371 \text { Do Multinational Enterprises Substitute Parent Jobs for Foreign } \\
\text { Ones? Evidence from Firm Level Panel Data }\end{array}$ & Jozef Konings and Alan Murphye & Apr. 2001 \\
\hline $\begin{array}{l}\text { No. } 370 \text { From Needs to the Market: Changing Inequality of Household } \\
\text { Income in the Czech Transition }\end{array}$ & Jiri Vecernik & Apr. 2001 \\
\hline $\begin{array}{l}\text { No. } 369 \text { Competition and Corporate Governance: Substitutes or } \\
\text { Complements? Evidence from the Warsaw Stock Exchange }\end{array}$ & $\begin{array}{l}\text { Irena Grosfeld and Thierry } \\
\text { Tressel }\end{array}$ & Mar. 2001 \\
\hline $\begin{array}{l}\text { No. } 368 \text { Multinational Corporations as Catalyst for Industrial } \\
\text { Development: The Case of Poland }\end{array}$ & $\begin{array}{l}\text { Carlo Altomonte and Laura } \\
\text { Resmini }\end{array}$ & Feb. 2001 \\
\hline No. 367 A Multi-Task Theory of the State Enterprise Reform & $\begin{array}{l}\text { Chong-En Bai, David D. Li, } \\
\text { Zhigang Tao, and Yijiang Wang }\end{array}$ & Mar. 2001 \\
\hline No. 366a Confidence Building in Emerging Stock Markets & Enrico C. Perotti and Luc Laeven & June 2001 \\
\hline No. 366 Confidence Building in Emerging Stock Markets & $\begin{array}{l}\text { Enrico C. Perotti, Luc Laeven, } \\
\text { and Pieter van Oijen }\end{array}$ & Dec. 2000 \\
\hline $\begin{array}{l}\text { No. } 365 \text { Incentive Contracting versus Ownership Reforms: Evidence } \\
\text { from China's Township and Village Enterprises }\end{array}$ & $\begin{array}{l}\text { Chun Chang, Brian McCall, and } \\
\text { Yijang Wang }\end{array}$ & Nov. 2000 \\
\hline $\begin{array}{l}\text { No. } 364 \text { Individual Pay and Outside Options: Evidence from the Polish } \\
\text { Labour Force Survey }\end{array}$ & $\begin{array}{l}\text { Fiona Duffy and Patrick Paul } \\
\text { Walsh }\end{array}$ & Mar. 2001 \\
\hline $\begin{array}{l}\text { No. } 363 \text { Investment, Credit Rationing and the Soft Budget Constraint: } \\
\text { Evidence from Czech Panel Data (revised Davidson Institute Working } \\
\text { Paper No. 60a) }\end{array}$ & Lubomír Lízal and Jan Svejnar & Feb. 2001 \\
\hline
\end{tabular}

